Article

\title{
What Drives the Use of Organic Fertilizers? Evidence from Rice Farmers in Indo-Gangetic Plains, India
}

\author{
Praveen Koovalamkadu Velayudhan ${ }^{1}{ }^{1}$, Alka Singh ${ }^{1, *}$, Girish Kumar Jha ${ }^{1}$, Pramod Kumar ${ }^{1}$, \\ Kingsly Immanuelraj Thanaraj ${ }^{2}$ and Aditya Korekallu Srinivasa ${ }^{1}$ \\ 1 Indian Council of Agricultural Research, Indian Agricultural Research Institute, New Delhi 110012, India; \\ veenkv@gmail.com (P.K.V.); girish.stat@gmail.com (G.K.J.); pramod.iari@gmail.com (P.K.); \\ adityaag68@gmail.com (A.K.S.) \\ 2 Indian Council of Agricultural Research, National Institute of Agricultural Economics and Policy Research, \\ New Delhi 110012, India; ecokingsly@yahoo.co.in \\ * Correspondence: asingh.eco@gmail.com
}

\section{check for}

updates

Citation: Koovalamkadu Velayudhan, P.; Singh, A.; Jha, G.K.; Kumar, P.; Immanuelraj Thanaraj, K.; Korekallu Srinivasa, A. What Drives the Use of Organic Fertilizers? Evidence from Rice Farmers in Indo-Gangetic Plains, India. Sustainability 2021, 13, 9546. https:// doi.org/10.3390/su13179546

Academic Editors: Francisco Pedrero Salcedo and Lewis Holloway

Received: 14 March 2021

Accepted: 5 May 2021

Published: 25 August 2021

Publisher's Note: MDPI stays neutral with regard to jurisdictional claims in published maps and institutional affiliations.

Copyright: (c) 2021 by the authors. Licensee MDPI, Basel, Switzerland. This article is an open access article distributed under the terms and conditions of the Creative Commons Attribution (CC BY) license (https:/ / creativecommons.org/licenses/by/ $4.0 /)$.

\begin{abstract}
There is a growing concern about the sustainability of agriculture due to the indiscriminate use of chemical fertilizers in several parts of the world. In India, the Indo-Gangetic Plain (IGP) is a region where the externalities of excessive use of chemical fertilizers for cereal production manifest in groundwater pollution, air pollution due to emissions, and soil degradation. In this context, we study the adoption of organic fertilizers in the region and the determining factors. We use data collected from 400 rice farmers to empirically test the link between farmers' perceptions, revenue expectations, socioeconomic factors, and the policy environment to adopt organic fertilizers. We use Tobit and Cragg's double hurdle model to study the farmers' expenditure and adoption of organic fertilizers, respectively. The results show that only $32 \%$ of the farmers adopted organic fertilizers in the region. Further, membership in farmer organizations, training, and education are the key variables that determine the adoption of organic fertilizers, in addition to a positive perception of the benefits of their usage. The findings highlight the need for efficient extension efforts in organic fertilizers and suggest policy interventions that promote collective learning through farmer groups.
\end{abstract}

Keywords: sustainability; technology adoption; green technology; soil fertilization; organic fertilizer

\section{Introduction}

Fertilizers have played a crucial role in raising global food production and achieving food security [1]. The close causal link between global cereal production and chemical fertilizer consumption is widely acknowledged [2]. Though regional variations exist, in general, Nitrogen (N) fertilizer use is estimated to have contributed $40 \%$ to the increases in the world's per capita food production [3]. N fertilizer's direct effect on food production has driven its global consumption growth upwards of nine times from the consumption level of the 1960s [4]. However, with increasing $\mathrm{N}$ consumption, more unutilized $\mathrm{N}$ is also released to the environment through leaching, volatilization, nitrification, and denitrification [5-7], since crop uptake amounts to only about $30 \%$ to $50 \%$ of the total fertilizers applied to soil [8]. Overuse of chemical fertilizers leads to soil and water contamination issues and greenhouse gas emissions, thus polluting the environment $[9,10]$. Continuous overuse of fertilizers can negatively affect the soil quality and structure of the soil microbial community [11], resulting in the decline of soil organic matter and faster acidification of soil [12]. Thus, reducing chemical fertilizer application without threatening food security to maintain agriculture sustainability is a challenge [13]. In India, being an agriculturedependent nation, the situation warrants immediate attention considering the present level of fertilizer use, the use efficiency of nutrients, and the emissions and leaching that affect the environment [14]. 
India is the second-largest consumer of chemical fertilizers in the world after China. India consumed about 17.6 million tonnes of Nitrogen $(\mathrm{N}), 6.9$ million tonnes of Phosphate (P), and 2.7 million tonnes of Potash (K) fertilizers in 2018 [15]. Higher fertilizer use contributed to about half of India's grain production during the 1970s and 1980s [16]. Increased fertilizer use was a part of the transformation of Indian agriculture through the green revolution, to which pockets such as the Indo-Gangetic Plains (IGPs) responded favourably by the rapid adoption of the use of chemical fertilizers, High Yielding Varieties (HYVs), pesticides, machines, and irrigation [17]. Notwithstanding that such a rapid transformation has helped to feed the country's enormous population, in recent years, there has been an increasing concern related to the environmental effects of indiscriminate use of fertilizers [18]. The pertinent question is how to continue increasing food production without disturbing the environment [8].

Technological and policy interventions can help address the problem of fertilizer overuse [19-21]. The development and successful diffusion of technologies and policies will largely direct farming towards sustainability [22]. Amongst the strategies, organic fertilizers can act as a useful measure towards this end [23]. Organic fertilizer application has several potential benefits in the form of improving soil structure [24] and synergistic effect on soil microbial diversity [25] in addition to the production of safer food for consumers, which fetches premium prices in the market [26]. The gradual improvement in the soil properties due to organic fertilizers will eventually also result in higher crop yields [27]. Additionally, organic fertilizer use reduces the vulnerability of the cropping systems to climatic variabilities as well, thus demanding its improved adoption in the future $[28,29]$. Considering these potential benefits, the use of organic fertilizers and/or the reduced level of chemical fertilizers can contribute towards a sustainable future [30-32]. The Government of India has also emphasized this recently by setting up schemes such as Paramparagat Krishi Vikas Yojana, Rashtriya Krishi Vikas Yojana, National Mission for Sustainable Agriculture, National Program for Organic Production, and National Project on Organic Farming, which promote organic fertilizer use in farming [33,34]. Though the benefits of using organic fertilizers are widely recognized, their adoption at the farm level is still low in India, owing to several constraints [35]. The risk associated with using organic fertilizers in reduced yields, increased pest attack, disease incidence, and higher production cost could discourage the farmers from its use [36]. The fertilizer selection (chemical or organic) and application (rate of application) by the farmers may depend on several factors [1]. The farmer and farm-specific characteristics, farmers' expectation of profits, the prevailing policy regime, and sales/marketing channels or arrangements can all affect the organic fertilizer adoption and level of use [9]. Farmers' perceptions of organic fertilizers and their risk attitude is another vital factor determining this technology's adoption [37,38].

Several studies have examined the determinants of organic farming adoption, but very few studies have explicitly dealt with the determinants of organic fertilizer adoption. Most importantly, adoption decisions and the level (quantity) of the use of organic fertilizers are sequential decisions. The estimation of the factors affecting them needs suitable econometric methods, which were lacking in earlier studies. To fill this research gap, we use data from a comprehensive rural household survey in the Indo-Gangetic Plains to empirically test the linkages between farmers' perceptions, socioeconomic characteristics, policy variables promoting the technology adoption, and the use of organic fertilizers. Farmers cultivating rice are included in this study, as the rice-wheat farming system is most common in the region [39]. Farmers in the region have followed input-intensive farming practices since the green revolution, and hence it is an excellent case to study their perception and preferences towards organic fertilizers. The study explores the extent of the adoption of organic fertilizers by the farmers and identifies the driving factors. Understanding the determinants of organic fertilizer adoption can provide valuable insights for policymakers with empirical evidence to formulate greener inputs strategies without compromising the output. 


\section{Materials and Methods}

\subsection{Data}

The study utilizes the data collected from 400 rice farmers of the IGP, India, from March to June 2020. The IGP region of India is vast, spanning from Punjab in the Northwest to West Bengal in the East [40]. Farmers there follow an input-intensive rice-wheat cropping system, and a large number of them grow Basmati rice, which fetches premium prices in the international market [41]. Yield stagnation, the decline in the groundwater table, soil degradation, and atmospheric pollution questions the sustainability of rice cultivation in IGP [42]. Nevertheless, excessive fertilizer use, especially $\mathrm{N}$, continues in the region, leading to nitrate leaching and groundwater pollution [43]. Along with this, the inadequate use of organic manures increases the risk of low yield response of the crop [44]. Judicious use of chemical fertilizers, along with organic fertilizers, as per the results of a soil test, is the key to sustaining the cropping system [45]. These prevailing cropping practices and resulting sustainability and environmental concerns encouraged us to select IGP to study organic fertilizer usage. Though both rice and wheat are grown in the study area in rotation, the farmers' expectations on returns are higher from rice than wheat. This is because farmers grow wheat mainly for government procurement agencies and/or the national market, as well as rice for export markets. Due to this, we presume that farmers make better decisions on input use (including that for organic fertilizers) in rice in comparison to wheat. Hence, we select rice as the crop of our interest in this study. We used a multistage sampling technique to collect the primary data from the IGP (Figure 1). In the first stage, we randomly selected Karnal from the Upper Gangetic Plains and Gorakhpur from the Middle Gangetic Plains, among the region's districts. These districts fall under different transect zones of IGP and have varying levels of agrarian dynamism. In the second stage, we selected one block from each district (Karnal block from Karnal district and Bansgaon block from Gorakhpur district) based on the maximum area under rice cultivation. We randomly selected four villages (Kalampura, Kachhwa, Sangohi, and Landhora from the Karnal block; Basauli, Dhobauli, Siswan, and Bharohia from Bansgaon block). In the final stage, 50 farmers were selected randomly from each of the eight selected villages that enabled us to survey the farmers and collect data from a total of 400 rice farmers, of which only $32 \%$ of farmers adopted organic fertilizers.

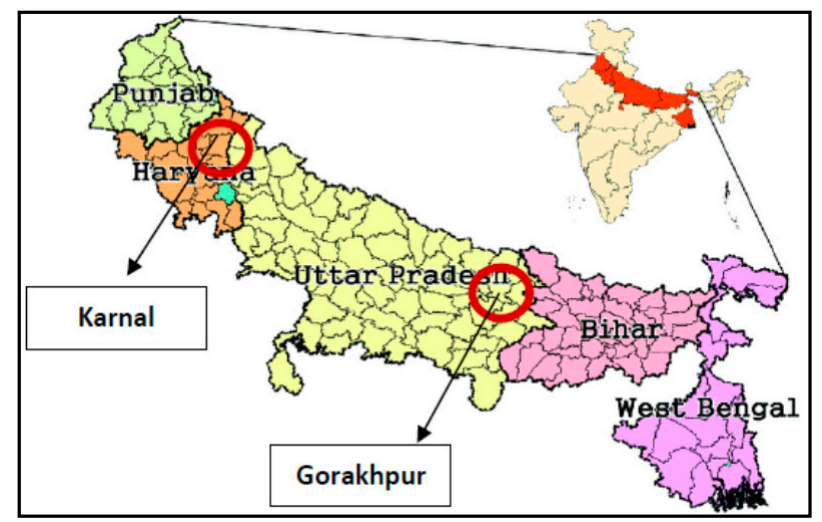

(a)

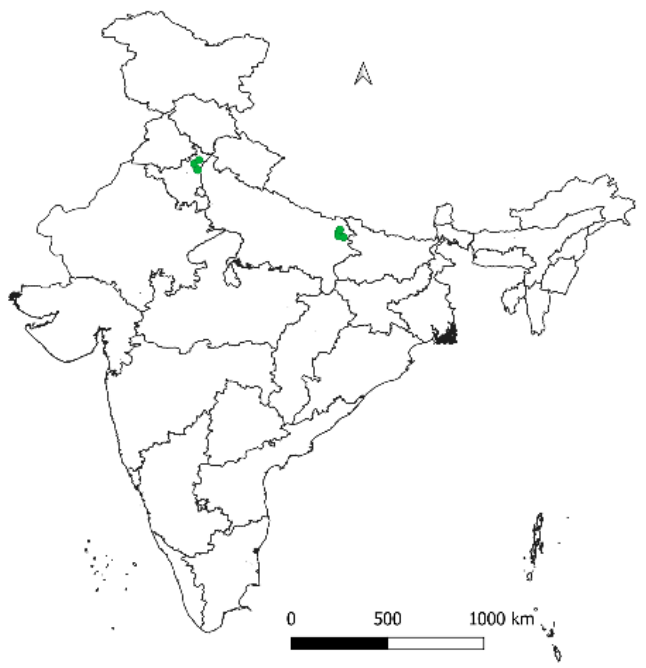

(b)

Figure 1. Map of the study area (Indo-Gangetic Plains region of India): (a) study districts from the IGP selected for the primary survey; (b) location of the sample villages. 
The data required for the study were collected using a structured schedule that consisted of questions on the demographic characteristics, household characteristics, farm characteristics of individual farmers, and farming practices followed by them. We also included questions on farmers' perceptions of organic fertilizers and their risk preferences. Table 1 presents the descriptive statistics of the variables used in the study. While all the farmers used chemical fertilizers, only $32 \%$ used organic fertilizers in their rice fields. Although Farm Yard Manure (FYM) is the major organic fertilizer used by the farmers in the sample, some have also used biofertilizers and commercial organic fertilizer products. For analysis in this study, we consider FYM use and expenditure synonymously to organic fertilizer use and expenditure. Farmers, on average, spent five times more on chemical fertilizer in comparison to organic. We calculated a risk score for individual farmers using their responses to a set of questions specially designed for the purpose. The farmers average risk score was 3.38 , indicating a relative risk-preferring group $(1=$ most risk-averse, $5=$ most risk-preferring) who are ready to invest in newer technologies. While $17 \%$ of the farmers have attended at least one training on organic fertilizers, $26 \%$ happened to be members of any farmer organization or cooperative.

Table 1. Descriptive statistics of variables used in the study.

\begin{tabular}{|c|c|c|}
\hline Variable & Definition & $\begin{array}{l}\text { Mean (Std. Dev.)/per } \\
\text { cent }\end{array}$ \\
\hline Uses organic fertilizers & 1 if the farmer uses organic fertilizer, 0 otherwise & $0.32(0.47)$ \\
\hline Gender & 1 if the farmer is male, 0 otherwise & $0.96(0.20)$ \\
\hline Age & Age of the farmer in years & 48.01(11.61) \\
\hline Disadvantaged section & $\begin{array}{c}1 \text { if the farmer belongs to Scheduled caste or Scheduled } \\
\text { Tribes, } 0 \text { otherwise }\end{array}$ & $0.10(0.29)$ \\
\hline Education & Formal education of the farmer in years & $7.84(3.48)$ \\
\hline Farming experience & Farming experience in years & $29.57(13.39)$ \\
\hline Tenure security & $\begin{array}{l}1 \text { if the tenancy status/land user right of the farmer } \\
\text { changes within the next five years, } 0 \text { otherwise }\end{array}$ & $0.01(0.11)$ \\
\hline Soil health card & 1 if the soil health card is issued to the farmer, 0 otherwise & $0.51(0.50)$ \\
\hline Membership & $\begin{array}{c}1 \text { if the farmer is a member of any farmer } \\
\text { organization/cooperative }\end{array}$ & $0.27(0.44)$ \\
\hline Training & 1 if the farmer had received training on organic fertilizers & $0.17(0.38)$ \\
\hline Distance to the farm & $\begin{array}{l}\text { Farmers' self-reported distance to the farm from home } \\
\qquad(1=\text { near, } 0=\text { far })\end{array}$ & $0.79(0.41)$ \\
\hline Asset & Average value of farm asset in INR & $249,166.23(417,401.62)$ \\
\hline Risk score & $\begin{array}{l}\text { Risk score calculated based on data collected on a 5-point } \\
\text { scale } \\
\text { (lower score indicates risk aversion) }\end{array}$ & $3.38(0.74)$ \\
\hline Size of farm holdings & Size of the farm in hectares & $1.64(1.69)$ \\
\hline \multirow[t]{2}{*}{ Soil fertility } & $\begin{array}{l}\text { Farmers' self-reported status of farm soil fertility } \\
\quad(5 \text {-point scale: } 1 \text { = worst; } 5 \text { = very good) }\end{array}$ & $3.85(0.72)$ \\
\hline & Status of fertilizer application & \\
\hline Chemical fertilizer & Chemical fertilizers applied in kilograms & $190.21(64.58)$ \\
\hline $\begin{array}{l}\text { Expenditure on chemical } \\
\text { fertilizer }\end{array}$ & Cost of the chemical fertilizers in INR & $4241.60(1440.18)$ \\
\hline Organic fertilizer & Quantity of organic fertilizers applied in quintals & $0.77(1.72)$ \\
\hline $\begin{array}{l}\text { Organic fertilizer } \\
\text { expenditure }\end{array}$ & Cost of the organic fertilizers in INR & $734.29(1649.56)$ \\
\hline
\end{tabular}


Table 1. Cont.

\begin{tabular}{|c|c|c|}
\hline Variable & Definition & $\begin{array}{l}\text { Mean (Std. Dev.)/per } \\
\text { cent }\end{array}$ \\
\hline \multicolumn{3}{|c|}{ Farmers' perceptions towards organic fertilizers (5-point scale: $1=$ strongly agree; $5=$ strongly disagree) } \\
\hline \multirow{4}{*}{$\begin{array}{c}\text { Reduce yield } \\
\text { Better output price } \\
\text { Increases pest and disease } \\
\text { attack } \\
\text { Better acceptance in the } \\
\text { market }\end{array}$} & Organic fertilizer will reduce yield & $3.08(1.14)$ \\
\hline & Organic fertilizer will help fetch a better price for output & $2.53(0.90)$ \\
\hline & Organic fertilizer increases pest and disease attack & $3.08(0.84)$ \\
\hline & $\begin{array}{l}\text { Organic fertilizer will help realize better acceptance in the } \\
\text { market }\end{array}$ & $2.64(0.81)$ \\
\hline \multicolumn{3}{|c|}{$\begin{array}{l}\text { Farmers' perceptions towards policy variables for promoting organic fertilizers (5-point scale: } 1=\text { strongly agree; } \\
\qquad 5=\text { strongly disagree) }\end{array}$} \\
\hline Output sale contract & Output sale contract needed for using organic inputs & $2.63(1.07)$ \\
\hline Farm certification & The farm should be certified if I use organic fertilizers & $2.40(1.16)$ \\
\hline Subsidy & I need a subsidy to use organic fertilizers & $2.18(1.59)$ \\
\hline Extension support & I need better extension support to use organic fertilizers. & $2.04(1.39)$ \\
\hline
\end{tabular}

\subsection{Methodology}

We analyzed the data in two stages-the fertilizer expenditure models in the first stage, and the adoption and use of organic fertilizer in the second stage. We started by estimating the fertilizer expenditure models for both chemical and organic fertilizers. Since all the farmers used chemical fertilizers, we used Ordinary Least Square (OLS) regression to estimate the determinants of chemical fertilizer expenditure. When the dependent variable was censored, that is, when the observation accumulated at the limit of the range of the variable, the OLS model was not useful. The lower limit of the range was zero in the case of variable organic fertilizer use, and observations accumulated at this limit. The Tobit model, a censored regression model, was thus used to estimate the covariates of organic fertilizer expenditure, which was appropriate since only $32 \%$ of the farmers used organic fertilizers. We used the same set of independent variables in both the models to compare and contrast the differences in fertilizer expenditure behaviours of farmers.

We specify the Tobit model as:

$$
\begin{gathered}
Y_{i}^{*}=\beta_{1} X_{i}+\beta_{2} P_{i}+\beta_{3} R S_{i}+\varepsilon_{i} \\
Y_{i}=Y_{i}^{*}, \text { if } Y_{i}^{*}>0 \text { and } Y_{i}=0, \text { if } Y_{i}^{*} \leq 0
\end{gathered}
$$

The latent variable $Y_{i}^{*}$ in Equation (1) is a stochastic variable to measure the organic fertilizer expenditure in Rupees (INR) per hectare rice area by the farmer $i . X_{i}$ represents the set of socioeconomic variables that can affect the adoption of organic fertilizers, and $P_{i}$ includes the variables to capture the farmer's perception of organic fertilizers. We assumed that the attitude towards risk can also affect the adoption of new technologies by the farmers. Hence, the variable $R S_{i}$ is included in the model to represent the risk score of the farmer. The final term $\varepsilon_{i}$ in Equation (1) represents the random disturbance term, while $\beta_{1}, \beta_{2}$, and $\beta_{3}$ refer to the coefficients of the parameters to be estimated. Equation (2) provides the relation between the observed expenditure on organic fertilizers $Y_{i}$ and the latent variable $Y_{i}^{*}$.

Next, to estimate the covariates of expenditure on chemical fertilizers by the farmers, we used OLS regression. The OLS approach was appropriate since all the farmers surveyed used chemical fertilizers. The OLS model was specified as in Equation (3),

$$
Y_{i}=\alpha_{1} X_{i}+\alpha_{2} P_{i}+\alpha_{3} R S_{i}+\varepsilon_{i}
$$


where $Y_{i}$ represents the farmer's expenditure on chemical fertilizers in INR per ha, and all the other variables are the same as in Equation (1). Finally, the parameters to be estimated by the model are $\alpha_{1}, \alpha_{2}$, and $\alpha_{3}$. We also performed a variance inflation factors (VIFs) test, following OLS regression, to detect multicollinearity among the independent variables.

We estimated the organic fertilizer use (quintals per hectare rice area) by Cragg's double hurdle model in the second stage. Unlike the first stage, where the prime objective of the analysis was to compare the expenditure behaviours of farmers between chemical and organic fertilizers, here we estimated the covariates of adoption and use (measured in physical quantity) of organic fertilizers. Upon data examination, we found that $68 \%$ of farmers reported using no organic fertilizers (nonadopters). The Tobit model of the first stage could be applied under the assumption that there being zero observations was due to economic factors, but it cannot explain there being zero observations due to nonparticipation. Cragg's double hurdle model can be useful in this aspect. The advantage of using Cragg's double hurdle model is that it allows considering the hurdles that the farmers need to overcome to become adopters of organic fertilizers at first, and then provide the estimates of variables that determine the level of organic fertilizer use [1]. It allows separate stochastic processes for adoption and level of use decisions. These are separately captured as the selection and outcome equations in the model, as specified below:

$$
\begin{aligned}
& Z_{i}^{*}=\beta_{1} X_{i}+\beta_{2} P_{i}+\beta_{3} R S_{i}+u_{i} \\
& Y_{i}^{*}=\alpha_{1} X_{i}+\alpha_{2} P_{i}+\alpha_{3} R S_{i}+v_{i}
\end{aligned}
$$

The adoption of organic fertilizer is represented by the latent variable $Z_{i}^{*}$ and the level of organic fertilizer use by the latent variable $Y_{i}^{*}$. While $\beta_{1}, \beta_{2}$, and $\beta_{3}$, as well as $\alpha_{1}, \alpha_{2}$, and $\alpha_{3}$, represent the parameters to be estimated, the terms $u_{i}$ and $v_{i}$ denote the errors that are assumed to be disturbed normally and independently with zero mean and a constant variance [46]. The relation between observed expenditure $Y_{i}$ and latent expenditure variable $Y_{i}^{*}$ is as per Equation (6).

$$
Y_{i}=Y_{i}^{*}, \text { if } Z_{i}^{*}>0 \text { and } Y_{i}=0 \text {, if } Z_{i}^{*} \leq 0
$$

The motives behind adopting organic fertilizers and the quantity of use of organic fertilizers are complex. Therefore, we assumed the set of independent variables that affect the outcome equation and selection equation were the same, except for the set of variables on perception towards policy variables for promoting organic fertilizer use. This is because the farmers who have not adopted organic fertilizers would be handicapped in terms of formulating appropriate perceptions towards these variables.

\section{Results}

\subsection{Comparison of Adopters and Nonadopters}

Among the sampled farmers, only $32 \%$ were adopters of organic fertilizers. In Table 2, we provide adopters' characteristics to test if they are different from the nonadopters in any aspect. The difference among adopters and nonadopters in the observed characteristics were tested using pairwise $t$-tests. We found the adopters' ages and farming experience to be significantly lower than that of the nonadopters and their education to be significantly higher. There was a significant difference in other variables such as training, membership, asset, farm size, tenure security, the holding of the soil health card, and perception towards organic fertilizers. Interestingly, there was no difference among the two groups in the chemical fertilizer expenditure and quantity used, indicating that even the adopters of organic fertilizers are not ready to use lesser quantities of chemical fertilizers. 
Table 2. Summary of critical variables for organic fertilizer adopters and nonadopters.

\begin{tabular}{cccc}
\hline Variables & Nonadopter & Adopter & Mean Difference \\
\hline Gender & 0.96 & 0.95 & 0.018 \\
Age & 50.35 & 43.03 & $7.314^{* * *}$ \\
Disadvantaged section & 0.11 & 0.06 & $0.059^{*}$ \\
Education & 6.84 & 9.97 & $-3.127^{* * *}$ \\
Farming experience & 31.88 & 24.66 & $7.215^{* * *}$ \\
Tenure security & 0.00 & 0.04 & $-0.039 * * *$ \\
Soil health card & 0.43 & 0.70 & $-0.269^{* * *}$ \\
Membership & 0.11 & 0.59 & $-0.472^{* * *}$ \\
Training & 0.01 & 0.52 & $-0.516^{* * *}$ \\
Distance to the farm & 0.77 & 0.81 & -0.04 \\
Asset & 160,000 & 440,000 & $-2.8 \times 10^{* * * *}$ \\
Risk score & 3.40 & 3.35 & 0.055 \\
Farm area & 1.26 & 2.46 & $-1.201^{* * *}$ \\
Soil fertility & 3.88 & 3.80 & 0.078 \\
\hline & Status of fertilizer application & \\
\hline Chemical fertilizer & 186.97 & 197.08 & -10.105 \\
Chemical fertilizer expenditure & 4169.49 & 4394.83 & -225.343 \\
Organic fertilizer expenditure & 0.00 & 2294.65 & $-2295^{* * *}$ \\
\hline
\end{tabular}

Farmers' perceptions towards organic fertilizers

(5-point scale: 1 = strongly agree; 5 = strongly disagree)

\begin{tabular}{cccc}
\hline Reduce yield & 2.71 & 3.87 & $-1.158^{* * *}$ \\
Better output price & 2.63 & 2.31 & $0.328^{* * *}$ \\
Increases pest and disease attack & 2.80 & 3.66 & $-0.855^{* * *}$ \\
Better acceptance in the market & 2.80 & 2.29 & $0.512^{* * *}$ \\
\hline
\end{tabular}

Farmers' perceptions towards policy variables for promoting organic fertilizers (5-point scale: 1 = strongly agree; 5 = strongly disagree)

\begin{tabular}{cccc}
\hline Output sale contract & 2.44 & 3.02 & $-0.582 * * *$ \\
Farm certification & 2.04 & 3.17 & $-1.135^{* * *}$ \\
Subsidy & 1.26 & 4.14 & $-2.880^{* * *}$ \\
Extension support & 1.46 & 3.28 & $-1.822 * * *$ \\
\hline Note: ${ }^{* * *}$ and ${ }^{*}$ represent significance levels at $1 \%$ and $10 \%$, respectively, for the mean difference from $t$-test.
\end{tabular}

\subsection{Determinants of Fertilizer Expenditure}

Table 3 presents the regression results of expenditure for both chemical and organic fertilizers. It shows that the farm size and soil health card holding affected the chemical fertilizer expenditure positively and significantly. The larger farmers spent more on chemical fertilizers, suggesting that they used a higher amount of fertilizers, which may be due to their higher ability and purchasing power to buy the chemical fertilizers. However, the holding of the soil health card is supposed to reduce the chemical fertilizer use since the card provides the details on the soil fertility status of the farms and the nutrient requirements specific to the plot. As realized from the farmers' discussion, many of them could not use the information provided in the card effectively to decide on fertilization. Additionally, mostly only the large and educated farmers valued the soil health card's information. Farmers belonging to the disadvantaged section spent more on chemical fertilizers. They often depend fully on farming to earn their livelihoods, unlike their counterparts with multiple income sources. Hence, they invest more in chemical fertilizers with the expectation of extracting the maximum output from the crop. We also found that as the farmers' experience in farming increases, they reduce the chemical fertilizer expenditure. Among the other variables in the model, the farmers' perceptions that shifting to organic fertilizers will increase the pest and disease attack affected the expenditure in chemical 
fertilizers positively as expected. The variable's sign is negative since the variable captures the perception on a five-point scale in which higher values disagree with the statement. All the VIF values were less than 3 in the VIF test, suggesting our model specification to be devoid of multicollinearity.

Table 3. Determinants of fertilizer expenditure

\begin{tabular}{|c|c|c|}
\hline Variables & $\begin{array}{l}\text { Chemical Fertilizers } \\
\text { (OLS Model) }\end{array}$ & $\begin{array}{l}\text { Organic Fertilizers } \\
\text { (Tobit Model) }\end{array}$ \\
\hline Gender & $635.503 *(353.926)$ & $-354.529(497.459)$ \\
\hline Age & $3.779(8.628)$ & $-31.127 * *(15.306)$ \\
\hline Disadvantaged section & $511.414 * *(246.342)$ & $432.020(408.153)$ \\
\hline Education & $-0.072(21.809)$ & $72.628^{* *}(31.906)$ \\
\hline Farming experience & $-19.789^{* * *}(7.497)$ & $-2.971(13.429)$ \\
\hline Tenure security & $567.208(652.401)$ & $-882.168(633.691)$ \\
\hline Soil health card & $326.366^{* *}(152.108)$ & $-150.409(231.138)$ \\
\hline Membership & $134.800(186.681)$ & $1293.679 * * *(241.526)$ \\
\hline Training & $-187.538(261.156)$ & $-222.648(283.939)$ \\
\hline Distance to farm & $27.957(179.016)$ & $13.863(273.912)$ \\
\hline Asset & $0.001(0.001)$ & $0.00(0.001)$ \\
\hline Risk score & 99.451 (95.582) & $-148.817(149.030)$ \\
\hline Farm size & $247.855^{* * *}(45.435)$ & $948.213^{* * *}(53.560)$ \\
\hline Soil fertility & $-25.998(95.078)$ & $50.222(120.851)$ \\
\hline Reduce yield & $-2.056(71.340)$ & $461.185^{* * *}(105.938)$ \\
\hline Better output price & $121.27(85.203)$ & $-241.947 * *(119.061)$ \\
\hline $\begin{array}{c}\text { Increases pest and disease } \\
\text { attack }\end{array}$ & $-246.960 * *(100.347)$ & 144.587 (139.923) \\
\hline Better acceptance in market & $-112.811(97.540)$ & $56.991(140.245)$ \\
\hline Output sale contract & $-1.972(71.116)$ & $-151.342(95.477)$ \\
\hline Farm certification & $65.076(70.411)$ & $146.670 *(87.846)$ \\
\hline Subsidy & $-11.051(64.822)$ & $614.419 * * *(71.142)$ \\
\hline Extension support & $-4.826(65.524)$ & $177.854 *(78.050)$ \\
\hline Constant & $3774.115^{* * *}(840.760)$ & $-4632.550 * * *(1270.989)$ \\
\hline Observations & 400 & 400 \\
\hline F value & $4.15^{* * *}$ & \\
\hline LR chi2 & & $500.90^{* * *}$ \\
\hline
\end{tabular}

Notes: The outcome variable is chemical and organic fertilizer expenditure per hectare in INR, respectively. Standard errors in parentheses, ${ }^{* * *} p<0.01,{ }^{* *} p<0.05,{ }^{*} p<0.1$.

Interestingly, a different set of variables influences the expenditure on organic fertilizers, among which those referring to the perception of farmers towards organic fertilizers were key. Among these, the farmers who disagreed with the statement that organic fertilizer use will reduce the yield and agreed that it would provide a better price to the output spent more on the organic fertilizers. Additionally, the farmers' contentment about the policy environment variables such as the current level of extension support and subsidies received and the status of farm certification encouraged organic fertilizer expenditure. Among the farmer characteristics, age and education were the crucial ones that affected the expenditure decision. Well-educated and young farmers were likely to spend more on organic fertilizers. Membership in farmer associations/cooperatives and farm size were the other determinants that positively affected the decision to invest. As large-sized farmers have better access to the information and can invest more, it is logical that they show a higher expenditure. The results are in line with Chen et al. [1]. The significance of membership re-emphasizes the fact that technology adoption can be better if promulgated through such groups. 


\subsection{Determinants of Organic Fertilizer Adoption and Use by Rice Farmers}

The determinants of organic fertilizer adoption and use were estimated using Cragg's double hurdle model. Table 4 presents the results and shows both the selection and outcome models. The organic fertilizer adoption decision (selection model) is significantly affected by the effects the farmers perceived with regard to organic fertilizer adoption. Their perceptions of organic fertilizer's effect on yield, output price, pest and disease attacks, and market acceptance were all associated with the adoption decision. The farmers who perceived that the yield would not be reduced and that pests and disease attacks will not be higher due to organic fertilizer being found to have a higher chance of adoption. Membership in farmer organizations and participation in organic fertilizer training also determined the adoption positively and significantly. The younger farmers showed better adoption, and the number of years of formal education also significantly affected it. Most of the variables that affected the adoption decision also significantly affected the level of organic fertilizer use (outcome model). Farmers who are young, educated, members of farmer organizations, participate in organic fertilizer training, have larger farm sizes, and have positive perceptions of organic fertilizers adopt organic fertilizers and use them at levels higher than the others. However, the perception that organic fertilizer use will increase pest and disease attacks and provide better acceptance in the market affected only the adoption and not the level of organic fertilizer use.

Table 4. Determinants of organic fertilizer adoption and use: results of Cragg's double hurdle model.

\begin{tabular}{|c|c|c|}
\hline Variables & Outcome Model & Selection Model \\
\hline Gender & $-0.255^{* *}(-0.124)$ & $-1.522 * *(0.652)$ \\
\hline Age & $-0.009^{* * *}(-0.003)$ & $-0.050^{* * *}(0.018)$ \\
\hline Disadvantaged section & $0.053(-0.14)$ & $-0.519(0.413)$ \\
\hline Farming experience & $-0.001(0.002)$ & $-0.002(0.016)$ \\
\hline Education & $0.022 * *(-0.011)$ & $0.192^{* * *}(0.046)$ \\
\hline Tenure security & 0.089 (13.717) & $3.772(201.838)$ \\
\hline Soil Health Card & $0.044(0.075)$ & $-0.069(0.294)$ \\
\hline Membership & $0.047^{* * *}(0.109)$ & $1.572 * * *(0.353)$ \\
\hline Training & $0.319 *(0.166)$ & $2.393^{* * *}(0.631)$ \\
\hline Distance to farm & $-0.076(0.087)$ & $0.665 *(0.342)$ \\
\hline Asset & $0.001(0.001)$ & $-0.001(0.001)$ \\
\hline Risk score & $0.014(0.051)$ & $-0.090(0.216)$ \\
\hline Farm size & $0.282 * * *(0.023)$ & $0.341^{* * *}(0.113)$ \\
\hline Soil fertility & $0.031(0.041)$ & $-0.093(0.178)$ \\
\hline Reduce yield & $0.106^{* * *}(0.036)$ & $0.654^{* * *}(0.138)$ \\
\hline Better output price & $-0.133^{* * *}(-0.043)$ & $-0.477^{* * *}(0.178)$ \\
\hline $\begin{array}{l}\text { Increases pest and disease } \\
\text { attack }\end{array}$ & $0.087 *(0.049)$ & $1.030^{* * *}(0.249)$ \\
\hline Better acceptance in market & $-0.056(0.049)$ & $-0.444^{* *}(0.192)$ \\
\hline Output sale contract & $-0.044 *(0.024)$ & \\
\hline Farm certification & $-0.017(0.023)$ & \\
\hline Subsidy & $0.037 *(0.020)$ & \\
\hline Extension support & $0.013(0.018)$ & \\
\hline Constant & 0.349 (1.621) & $-2.328(1.533)$ \\
\hline Observations & 400 & 400 \\
\hline LR chi2 & \multicolumn{2}{|c|}{$574.14^{* * *}$} \\
\hline Log-likelihood & \multicolumn{2}{|c|}{-203.13} \\
\hline
\end{tabular}

\section{Discussion}

Our analysis results provide meaningful insights into the organic fertilizer adoption and use by the farmers in the IGP region of India. All the explanatory variables included in 
the models were selected based on their hypothesized relation with the adoption decision and use level. We hypothesize that the farmers' expenditure on fertilizers is directly in line with their prospect revenue variables, such as the effect on yield, price, and the risk involved (in switching partially or wholly from chemical to organic fertilizer or vice versa). Farmers' perceptions of organic fertilizers were captured using these variables, and their significance in the model is in line with other studies [1,9]. The farmers who expect better yields and revenues with chemical fertilizers will continue to use them under normal circumstances unless they believe that supplementing the fertilizer mix with organic components could make a difference to their revenues. The prospect revenue variables, except risk, were found to encourage organic fertilizer use. The risk score did not affect the farmers' decisions, which is not in line with previous studies [47,48]. As noted earlier, the farmers in the IGP are those who adopted the green revolution technologies and contributed significantly to India's cereal production. The grain output from this region is generally exported or procured by the government agencies for distributing through the public distribution system; hence, they are ensured to receive a minimum price (Minimum Support Price) [49]. This may be the reason for the nonsignificance of the risk score of the farmers.

The farmers' perceptions and confidence in the existing marketing arrangement is another aspect that could play a part in decision-making. The need for contracts and their membership status in the farmer organizations/cooperatives depict this variable. Both of these variables encouraged organic fertilizer use significantly. The literature also suggests [36] that membership in farmer organizations will help the farmer to navigate the proper fertilization strategies by reducing excessive chemical fertilizers, which could prompt them to use more organic supplements. Training on organic fertilizer use is another variable that had a positive effect on its adoption. This finding complements the literature $[1,50]$ and suggests that the efforts of the government to educate farmers through training on different types of organic fertilizers, their suitability to different soil conditions, the time lag for the effects to be visible, and the method of adoption will pay off heavily in the future by helping them to embrace sustainability in the production systems. Socioeconomic characteristics such as age, education, and the farming experience can also affect the expenditure decision since younger lots are risk-takers, and education gives them access to better information. Additionally, higher farming experience results in a better understanding of the farm nutrient needs and helps realize the significance of organic fertilizers.

Among others, the set of variables that are part of the policy environment, including subsidy, the need for certification of farms or produce, and extension support, also encourages organic fertilizer adoption. Subsidies can help increase the level of use because the adopters in the region cannot use the recommended level of organic fertilizers, which may be due to monetary constraints. Since they understand the benefits of organic fertilizers and have crossed the adoption barrier, they may be better it if they receive support in the form of subsidies. Government actions also echo this, since there is a greater emphasis on organic fertilizers in several recently implemented agricultural development schemes [33]. The future impetus will be on the Decision Support Systems (DSSs) that enable assessing the effectiveness of organic fertilizers locally or regionally [51]. Such an organic fertilizer promotional strategy utilizing a DSS will go a long way in the journey of Indian agriculture towards a sustainable future [52,53].

To summarize, in this study, we have extracted the determinants that could affect the adoption and use of organic fertilizers. Although our analysis provides several meaningful insights, there are some limitations as well. The dependency between the two hurdles in the double hurdle model is assumed based on the underlying theory and not empirically tested, which is a limitation of the model. Additionally, we have considered only one among the two crops commonly cultivated within the region, and hence there are chances of underestimating the actual quantity of organic fertilizers applied to the farms. The results should thus be interpreted cautiously, considering the variation in farmers' perceptions 
and the crop and soil requirements across regions. Still, our findings can be valuable to areas with similar agroecological and socioeconomic characteristics to the IGP. Further research in this area can focus on the local social networks prevalent in the region, giving a micro view on the agencies and entities to be tapped to encourage better adoption and use of organic fertilizers. Randomized control trials on organic fertilizers are another future research option that can prove the technology's worth and spread the results fast among the stakeholders. Additionally, studies utilizing time-series data on similar aspects can be of great value in the future since they can provide better insights than cross-sectional data.

\section{Conclusions}

Using data from a comprehensive survey of rice farmers in IGP, India, we studied the expenditure on organic fertilizers and the factors determining its adoption and quantity used. We used the Tobit model to study farmers' expenditure in organic fertilizers and Cragg's double hurdle model to identify the factors determining its adoption and level of use in farming. We add valuable information to the literature by linking farmers' future revenue expectations, the prevailing marketing arrangements, socioeconomic factors, policy environment, and perception of technology with technology adoption and intensity of use. The findings are relevant since the adoption of organic fertilizers in the region was found to be lower, hence policy options should be suggested to increase its usage. We found that, in general, young, educated farmers who are members of farmer organizations, attended training, and positively perceived the effect of using organic fertilizers were the adopters and showed higher levels of use. Our findings have some policy implications as well, especially concerning the future strategies of soil fertilization in the region. First, the government should encourage the farmers to join together, form groups, and make collective farming decisions suitable for the local soil properties. The uneducated, older, and untrained farmers could also experience the benefits of organic fertilizers. Additionally, it will be more comfortable and practical if training is provided to farmer groups than individual farmers. Second, since the positive perception towards organic fertilizers plays a crucial role in its adoption and level of usage, more efforts to popularize the benefits of the technology should be undertaken by the government since it takes time before the technology reaches the majority. The problem with organic fertilizers is that their benefits may not have immediate visibility. The extension system has a huge role to play here to assure the farmers of the benefits of continuing with its usage. Third, although the subsidies are being criticized for being the most common government strategy for promoting chemical fertilizer usage, an altered strategy of providing a part of these subsidies to promote organic fertilizers can be effective in improving its usage. However, it is necessary to act beyond subsidies and create an enabling environment that can form farmer groups, avail necessary training, and perceive the actual benefits before they are reaped. Finally, if generated from different locations and conditions, more research evidence can help validate the findings that can guide policymaking to benefit a broader set of farmers, nationally and internationally.

Author Contributions: Conceptualization, P.K.V. and A.S.; methodology, P.K.V., G.K.J. and A.K.S.; software, P.K.V., G.K.J. and A.K.S.; validation, P.K.V., A.S., P.K., K.I.T., G.K.J. and A.K.S.; formal analysis, P.K.V., G.K.J. and A.K.S.; writing-original draft preparation, P.K.V., A.S. and K.I.T.; writingreview and editing, P.K.V. and A.S.; visualization, P.K.V., P.K. and K.I.T.; supervision, A.S.; funding acquisition, A.S. All authors have read and agreed to the published version of the manuscript.

Funding: This research was funded by NAHEP, Indian Council of Agricultural Research (ICAR), New Delhi, Grant No. NAHEP/CAAST/2018-19/07.

Institutional Review Board Statement: Not applicable.

Informed Consent Statement: Not applicable.

Data Availability Statement: The data presented in this study are available on request from the corresponding author. 
Acknowledgments: This paper is drawn from the first author's PhD research work entitled "Estimating the effects of fertilizer use in agriculture: implications for crop response and environmental sustainability" conducted at Division of Agricultural Economics, ICAR-Indian Agriculture Research Institute, New Delhi, India.

Conflicts of Interest: The authors declare no conflict of interest.

\section{References}

1. Chen, X.; Zeng, D.; Xu, Y.; Fan, X. Perceptions, Risk Attitude and Organic Fertilizer Investment: Evidence from Rice and Banana Farmers in Guangxi, China. Sustainability 2018, 10, 3715. [CrossRef]

2. Stewart, W.M.; Roberts, T.L. Food Security and the Role of Fertilizer in Supporting It. Procedia Eng. 2012, 46, 76-82. [CrossRef]

3. Smil, V. Nitrogen and Food Production: Proteins for Human Diets. Ambio 2002, 31, 126-131. [CrossRef] [PubMed]

4. Lu, C.; Tian, H. Global Nitrogen and Phosphorus Fertilizer Use for Agriculture Production in the Past Half Century: Shifted Hot Spots and Nutrient Imbalance. Earth Syst. Sci. Data 2017, 9, 181-192. [CrossRef]

5. Tilman, D.; Cassman, K.G.; Matson, P.A.; Naylor, R.; Polasky, S. Agricultural Sustainability and Intensive Production Practices. Nature 2002, 418, 671-677. [CrossRef]

6. Ranjan, R.; Yadav, R. Targeting Nitrogen Use Efficiency for Sustained Production of Cereal Crops. J. Plant Nutr. 2019, 42, 1086-1113. [CrossRef]

7. Kumar, A.; Medhi, K.; Fagodiya, R.K.; Subrahmanyam, G.; Mondal, R.; Raja, P.; Malyan, S.K.; Gupta, D.K.; Gupta, C.K.; Pathak, H. Molecular and Ecological Perspectives of Nitrous Oxide Producing Microbial Communities in Agro-Ecosystems. Rev. Environ. Sci. Biotechnol. 2020, 19, 717-750. [CrossRef]

8. Mózner, Z.; Tabi, A.; Csutora, M. Modifying the Yield Factor Based on More Efficient Use of Fertilizer-The Environmental Impacts of Intensive and Extensive Agricultural Practices. Ecol. Indic. 2012, 16, 58-66. [CrossRef]

9. Wang, Y.; Zhu, Y.; Zhang, S.; Wang, Y. What Could Promote Farmers to Replace Chemical Fertilizers with Organic Fertilizers? J. Clean. Prod. 2018, 199, 882-890. [CrossRef]

10. Zhang, X.; Davidson, E.A.; Mauzerall, D.L.; Searchinger, T.D.; Dumas, P.; Shen, Y. Managing Nitrogen for Sustainable Development. Nature 2015, 528, 51-59. [CrossRef]

11. Wu, L.; Jiang, Y.; Zhao, F.; He, X.; Liu, H.; Yu, K. Increased Organic Fertilizer Application and Reduced Chemical Fertilizer Application Affect the Soil Properties and Bacterial Communities of Grape Rhizosphere Soil. Sci. Rep. 2020, 10, 9568. [CrossRef] [PubMed]

12. Wang, J.; Li, R.; Zhang, H.; Wei, G.; Li, Z. Beneficial Bacteria Activate Nutrients and Promote Wheat Growth under Conditions of Reduced Fertilizer Application. BMC Microbiol. 2020, 20, 38. [CrossRef]

13. Duan, Y.; Xu, M.; Gao, S.; Liu, H.; Huang, S.; Wang, B. Long-Term Incorporation of Manure with Chemical Fertilizers Reduced Total Nitrogen Loss in Rain-Fed Cropping Systems. Sci. Rep. 2016, 6, 33611. [CrossRef] [PubMed]

14. Vitousek, P.M.; Naylor, R.; Crews, T.; David, M.B.; Drinkwater, L.E.; Holland, E.; Johnes, P.J.; Katzenberger, J.; Martinelli, L.A.; Matson, P.A.; et al. Agriculture. Nutrient Imbalances in Agricultural Development. Science 2009, 324, 1519-1520. [CrossRef] [PubMed]

15. Fertilizer Association of India. Fertilizer Statistics 2019-20; The Fertiliser Association of India: New Delhi, India, 2020.

16. Alexandratos, N.; Bruinsma, J. World Agriculture towards 2030/2050: The 2012 Revision. Available online: http:/ / www.fao.org/ 3/ap106e/ap106e.pdf (accessed on 5 May 2021).

17. Sandhu, H. Bottom-Up Transformation of Agriculture and Food Systems. Sustainability 2021, 13, 2171. [CrossRef]

18. Patra, S.; Mishra, P.; Mahapatra, S.C.; Mithun, S.K. Modelling Impacts of Chemical Fertilizer on Agricultural Production: A Case Study on Hooghly District, West Bengal, India. Model. Earth Syst. Environ. 2016, 2, 1-11. [CrossRef]

19. Sun, W.; Huang, Y. Synthetic Fertilizer Management for China's Cereal Crops Has Reduced $\mathrm{N}_{2} \mathrm{O}$ Emissions since the Early 2000s. Environ. Pollut. 2012, 160, 24-27. [CrossRef]

20. Fagodiya, R.K.; Pathak, H.; Bhatia, A.; Jain, N.; Kumar, A.; Malyan, S.K. Global Warming Impacts of Nitrogen Use in Agriculture: An Assessment for India since 1960. Carbon Manag. 2020, 11, 291-301. [CrossRef]

21. Fagodiya, R.K.; Pathak, H.; Bhatia, A.; Jain, N.; Gupta, D.K.; Kumar, A.; Malyan, S.K.; Dubey, R.; Radhakrishanan, S.; Tomer, R. Nitrous Oxide Emission and Mitigation from Maize-Wheat Rotation in the Upper Indo-Gangetic Plains. Carbon Manag. 2019, 10, 489-499. [CrossRef]

22. Lybbert, T.J.; Sumner, D.A. Agricultural Technologies for Climate Change in Developing Countries: Policy Options for Innovation and Technology Diffusion. Food Policy 2012, 37, 114-123. [CrossRef]

23. Das, A.; Patel, D.P.; Kumar, M.; Ramkrushna, G.I.; Mukherjee, A.; Layek, J.; Ngachan, S.V.; Buragohain, J. Impact of Seven Years of Organic Farming on Soil and Produce Quality and Crop Yields in Eastern Himalayas, India. Agric. Ecosyst. Environ. 2017, 236, 142-153. [CrossRef]

24. Pulleman, M.; Jongmans, A.; Marinissen, J.; Bouma, J. Effects of Organic versus Conventional Arable Farming on Soil Structure and Organic Matter Dynamics in a Marine Loam in the Netherlands. Soil Use Manag. 2003, 19, 157-165. [CrossRef]

25. Tu, C.; Ristaino, J.B.; Hu, S. Soil Microbial Biomass and Activity in Organic Tomato Farming Systems: Effects of Organic Inputs and Straw Mulching. Soil Biol. Biochem. 2006, 38, 247-255. [CrossRef] 
26. Gopinath, K.A.; Saha, S.; Mina, B.L.; Pande, H.; Kundu, S.; Gupta, H.S. Influence of Organic Amendments on Growth, Yield and Quality of Wheat and on Soil Properties during Transition to Organic Production. Nutr. Cycl. Agroecosyst. 2008, 82, 51-60. [CrossRef]

27. Martini, E.A.; Buyer, J.S.; Bryant, D.C.; Hartz, T.K.; Denison, R.F. Yield Increases during the Organic Transition: Improving Soil Quality or Increasing Experience? Field Crops Res. 2004, 86, 255-266. [CrossRef]

28. Yadav, C.; Pandey, S. Status of the Use of Organic Fertilizers in India: A Review. Agric. Rev. 2020, 41, 338-346. [CrossRef]

29. Khan, S.A.; Kumar, S.; Hussain, M.Z.; Kalra, N. Climate Change, Climate Variability and Indian Agriculture: Impacts Vulnerability and Adaptation Strategies. In Climate Change and Crops; Singh, S.N., Ed.; Environmental Science and Engineering; Springer: Berlin/Heidelberg, Germany, 2009; pp. 19-38. ISBN 978-3-540-88246-6.

30. van Diepeningen, A.D.; de Vos, O.J.; Korthals, G.W.; van Bruggen, A.H.C. Effects of Organic versus Conventional Management on Chemical and Biological Parameters in Agricultural Soils. Appl. Soil Ecol. 2006, 31, 120-135. [CrossRef]

31. Abedi, T.; Alemzadeh, A.; Kazemeini, S.A. Effect of Organic and Inorganic Fertilizers on Grain Yield and Protein Banding Pattern of Wheat. Aust. J. Crop. Sci. 2010, 4, 384-389.

32. Malyan, S.K.; Bhatia, A.; Kumar, S.S.; Fagodiya, R.K.; Pugazhendhi, A.; Duc, P.A. Mitigation of Greenhouse Gas Intensity by Supplementing with Azolla and Moderating the Dose of Nitrogen Fertilizer. Biocatal. Agric. Biotechnol. 2019, $20,101266$. [CrossRef]

33. Das, S.; Chatterjee, A.; Pal, T.K. Organic Farming in India: A Vision towards a Healthy Nation. Food Qual. Saf. 2020, 4, 69-76. [CrossRef]

34. Yadav, D.M. Towards A Healthier Nation: Organic Farming and Government Policies in India. Int. J. Adv. 2017, 2, 153-159.

35. Panneerselvam, P.; Halberg, N.; Vaarst, M.; Hermansen, J.E. Indian Farmers' Experience with and Perceptions of Organic Farming. Renew. Agric. Food Syst. 2012, 27, 157-169. [CrossRef]

36. Huang, J.; Huang, Z.; Jia, X.; Hu, R.; Xiang, C. Long-Term Reduction of Nitrogen Fertilizer Use through Knowledge Training in Rice Production in China. Agric. Syst. 2015, 135, 105-111. [CrossRef]

37. Yusuf, M.B.; Mustafa, F.B.; Salleh, K.O. Farmer Perception of Soil Erosion and Investment in Soil Conservation Measures: Emerging Evidence from Northern Taraba State, Nigeria. Soil Use Manag. 2017, 33, 163-173. [CrossRef]

38. Case, S.D.C.; Oelofse, M.; Hou, Y.; Oenema, O.; Jensen, L.S. Farmer Perceptions and Use of Organic Waste Products as FertilisersA Survey Study of Potential Benefits and Barriers. Agric. Syst. 2017, 151, 84-95. [CrossRef]

39. Mahajan, A.; Gupta, R.D. Integrated Nutrient Management (INM) in a Sustainable Rice-Wheat Cropping System; Springer: Dordrecht, The Netherlands, 2009. [CrossRef]

40. Bhatt, R.; Kukal, S.S.; Busari, M.A.; Arora, S.; Yadav, M. Sustainability Issues on Rice-Wheat Cropping System. Int. Soil Water Conserv. Res. 2016, 4, 64-74. [CrossRef]

41. Prasad, R. Phosphorus Management in the Rice-Wheat Cropping System of the Indo-Gangetic Plains. 2007. Available online: http: / / www.ipni.net/publication/bca.nsf/0/115081A5535096C9852579A4007AD4DF/\$FILE/bc-india_Nov07_p08.pdf (accessed on 25 February 2021).

42. Hobbs, P.R.; Gupta, R.K. Rice Wheat Cropping Systems in the Indo-Gangetic Plains: Issues of Water Productivity in Relation to New Resource Conserving Technologies; H032646, IWMI Books, Reports; International Water Management Institute: Giza, Egypt, 2003.

43. Sihi, D.; Dari, B.; Yan, Z.; Sharma, D.K.; Pathak, H.; Sharma, O.P.; Nain, L. Assessment of Water Quality in Indo-Gangetic Plain of South-Eastern Asia under Organic vs. Conventional Rice Farming. Water 2020, 12, 960. [CrossRef]

44. NAAS. Soil Health: New Policy Initiatives for Farmers' Welfare. Policy Brief 3. 2018. Available online: http:/ /naasindia.org/ documents/SoilHealth.pdf (accessed on 10 March 2021).

45. Chandini, K.R.; Kumar, R.; Prakash, O. The Impact of Chemical Fertilizers on Our Environment and Ecosystem. In Research Trends in Environmental Sciences, 2nd ed.; AkiNik Publications: New Delhi, India, 2019; pp. 69-86.

46. Aditya, K.S.; Jha, G.K.; Sonkar, V.K.; Saroj, S.; Singh, K.M.; Singh, R.K.P. Determinants of Access to and Intensity of Formal Credit: Evidence from a Survey of Rural Households in Eastern India. Agric. Econ. Res. Rev. 2019, 32. [CrossRef]

47. Ramaswami, B. Production Risk and Optimal Input Decisions. Am. J. Agric. Econ. 1992, 74, 860-869. [CrossRef]

48. Isik, M.; Khanna, M. Stochastic Technology, Risk Preferences, and Adoption of Site-Specific Technologies. Am. J. Agric. Econ. 2003, 85, 305-317. [CrossRef]

49. Aditya, K.S.; Subash, S.P.; Praveen, K.V.; Nithyashree, M.L.; Bhuvana, N.; Sharma, A. Awareness about Minimum Support Price and Its Impact on Diversification Decision of Farmers in India. Asia Pac. Policy Stud. 2017, 4, 514-526. [CrossRef]

50. Li, Q.; Yang, W.; Li, K. Role of Social Learning in the Diffusion of Environmentally-Friendly Agricultural Technology in China. Sustainability 2018, 10, 1527. [CrossRef]

51. Timsina, J. Can Organic Sources of Nutrients Increase Crop Yields to Meet Global Food Demand? Agronomy 2018, 8, 214. [CrossRef]

52. Sarkar, R. Decision Support Systems for Agrotechnology Transfer. In Organic Fertilisation, Soil Quality and Human Health; Lichtfouse, E., Ed.; Sustainable Agriculture Reviews; Springer: Dordrecht, The Netherlands, 2012; pp. 263-299. ISBN 978-94-007-4113-3.

53. Iftikar, W.; Chattopadhayay, G.N.; Majumdar, K.; Sulewski, G.D. Use of Village-Level Soil Fertility Maps as a Fertilizer Decision Support Tool in the Red and Lateritic Soil Zone of India. Proc. Int. Plant Nutr. Colloq. XVI 2010, 94, 3. 